\title{
Employees' emotional intelligence and service delivery to customers: A comparative study of selected deposit money banks in Nigeria and Liberia
}

\author{
Smith Farley Roland \\ Business Administration Programme, Bowen University, Iwo, Osun State, Nigeria
}

Akinbode James Olalekan

Industrial Relations and Personnel Management Programme

Bowen University, Osun State, Nigeria

Keywords

Bank, Customers, Emotional intelligence, Service delivery,

\begin{abstract}
For decades, service delivery challenges have remained contentious in both Nigerian and Liberian banking sector with studies pointing towards different reasons. This study examined one of the reasons which is employees' emotional intelligence as it determines service delivery to customers in selected deposit money banks of Nigeria and Liberia. Literature review captured employee emotional intelligence and customers service delivery to evolve gaps which set pace for this study. This provided the springboard with which the methodology adopted was built on. Specifically, survey design was adopted with both bank customers and employees in the main branches of the commercial centers of the countries as the population of the study. Bank customers and their employees were sampled with both purposive and convenience techniques. Two sets of questionnaires were adopted for the study: one for the customers and the other for bank employees. Data collected was analysed with appropriate statistical methods. Results revealed no significant difference in the deposit money banks customers' complaint rate in Nigeria and Liberia Banks; no significant difference between the employees' Emotional Intelligence level of Nigeria bank employees and Liberia bank employees; self-management is the only significant contributor to the quality of service delivery in Nigeria; while social skill, social awareness as well as self-management were the predictors that significantly contribute to the quality of banks service delivery in Liberia; and there is a significant combined influence of the predictors of employees' emotional intelligence on bank service delivery to customers in both countries. The study conclude that emotional intelligence is fundamental to service delivery to customers in both countries. It was recommended that bank management in both countries need to come up with purposeful employees' emotional training programs to improve employees' emotional intelligence competencies while individual employees should also seek knowledge on how to continuously enrich their emotional intelligence level.
\end{abstract}

\subsection{Introduction}

Service sector of any economy is consistently challenged by factors such as customers' taste preferences, government policies, competitors' strength, multiple choices of service providers, globalisation, to mention a few (Kalpana \& Noopur, 2013; Shahram, Mohmmad \& Mohammad, 2013). These have kept the sector on her toes, searching for the best ways through which the aforementioned factors can be addressed. According to Grönroos and Ravald (2011), the delivery of high-quality service is the fundamental interest of service providers in which employees' play critical roles in service delivery to customers. Jain, Jain and Das (2018) remarked that intelligent quotient of employee is not enough to deliver service efficiently, their emotional intelligence has become important to bring about efficient service delivery (Jain, Jain, \& Das, 2018).

Emotional intelligence is the capacity of an individual to manage emotions and is being noted as one of the leading determinants of harmonious relationship of members in a group (Nyerere \& Barasa, 2015). According to Graham and Roger (1998), it is the capacity to deplore intellect effectively that is mental functions of thinking, understanding, observing, learning, perceptional relationships and problem 
solving. It therefore entails the possession of self-management skills, self-awareness skills, and social skills. In an organisation like the bank, employees' EI is required to ensure efficient service delivery (Jain, Jain, \& Das, 2018). With the challenge of lack of efficient banking services delivery in Nigeria (Adeniji \& Akinbode, 2018; Farayibi, 2016; Odusina, 2014; Sanusi, 2012), suggest emotional intelligence gap among bank employees. This issue is also what is happening in many other developing countries like Liberia as evident in International Monetary Fund (2016) and Fitch ratings (2017) reports. Details of the reports revealed unimpressive performance of banking sector in both Nigeria and Liberia.

According to personality theory, individual traits such as self-awareness, empathy and adeptness which are significant to emotional intelligence are fundamental to efficient bank service delivery. Similarly, demand control theory which explored the extent to which individual is involved in job in terms of the ability to acquire new knowledge, evolve new skills, multi-task through skillsets, and display creativity that could address customers' needs contribute to the judgement of efficient service delivery. It is within this context that the study examined employees' EI and delivery of bank services among these banks in both Nigeria and Liberia.

\subsection{Literature Review}

\subsection{Emotional Intelligence}

Two basic words from this sub-title namely emotion and intelligence made up the concept 'emotional intelligence'. According to Consoli (2010), emotion is an organised mental reaction to occurrences based on cognitive disposition. The author further says that such reaction can manifest in facial, verbal, or textual expressions. On the secondhand intelligence', this is associated with individual ability or capacity. In the opinion of Wechsler (1958), it is the cumulative or total capacity of a person to performance deliberately, reason logically and transact successfully within a context. In summary, emotional intelligence can be said to be individual's ability to correctly recognise, perceive, purpose concerning and manage emotions, put in the facts to ease notion and reach aim (Killgore, Smith, Olson, Weber, Rauch \& Nickerson, 2017).

\subsection{Models of Employee Emotional Intelligence}

Three prototypes of emotional intelligence were reviewed under this sub-heading namely, Capacity, bar-on and Goleman mix models.

Capacity model: This prototype originated from the piece of Mayer and Salovey (1990) to explain key ideas that integrate emotion and intelligence which gave rise to EI. According to the model, reactions remain valuable foundations of facts and know how to support in making logic to traverse human environment.

Bar-On mixed Model: This prototype communicates to the prospective intended for performance, rather than performance itself in explaining EI as it was process-oriented against the outcome. The emphasis was on an array of emotional and social abilities such as ability to be aware of, understand and express oneself, ability to deal with strong emotions, and adapt to change and solving social or personal problems.

Goleman mix model: This model concentrated on emotional intelligence as a comprehensive collection of proficiencies and skills. Goleman (1995) identified construct of EI such as social awareness, self-awareness and self-management. The author suggests that individuals are born with general EI that determines their potentials for learning emotional competencies.

\subsection{Determinants of Employee EI}

Studies (Danquah, 2015; Georgiana, 2014; Pahuja, 2012) have identified basic determinants of employees' EI among which are social-talents, self-control, social-mindfulness, self-awareness, relationship-supervision, among others. Four of these determinants are of interest in this review. Which are.

Self-management: It entails the capacity of a person to regulate his or her conduct with a tendency to pursue aims with purposeful energy and perseverance. Georgina (2014) described it as one's ability to control emotional response to others by choosing correct emotional response and the concentration of that reaction. 
Self- awareness: This entails the capacity of a person to identify and his or her emotions, drives and those of others (Georgiana, 2014; Goleman, 1998). Chapman (2011) defined it as the capacity of a person to be conscious of one-self while Armstrong (2009) identified three competencies of self-awareness as selfassurance, truthful self-valuation, also emotional self-mindfulness.

Social awareness: This arises when a person knows present feeling using those preferences to direct policymaking, with self-valuation of capabilities and a knowledgeable sense of self-assurance.

Social skills: It is the ability in handling relationships as well as sustaining network to achieve desired outcomes through other and extent individual goal as well as find mutual ground and build support.

\subsection{EI in the Banking Industry}

Karthikeyan \& Lalwani (2017) and Swarnalatha \& Sekar (2016) gave their own account of EI in the banking industry in their respective studies. Both studies acknowledged the growing importance of EI in the industry. Other studies Naeem, Saif, and Khalil (2008), have also shown some evidences of its relevance. Kappagoda's (2013) study established that the level of EI changes with some demographic variables such as sexual characteristics, oldness and informative level in the Sri Lanka banking sector.

Additionally, Pahuja's (2012) study established the knowledge of EI among employees. The study highlighted self-awareness, self-management and empathy as the major EI traits of bank employees. Similarly, Thavaraj (2012) study revealed self-mindfulness, self- instruction, self-enthusiasm, socialmindfulness and social-talents, as determinants of EI in the industry. In Nigeria, Okon, Anietie and Abosede (2015) acknowledged that EI can be established at any period of life through an organized and consistent method and can help to improve job performance. The study of Danquah (2015) in Ghana also suggests the relevance of emotional intelligence in the banking industry owing to significance of this to financial performance of some selected banks in the areas of relationship marketing, customer happiness and service quality.

\subsection{Service Delivery as a Concept}

Service is a process made up of chain of extra or less intangible activities that might automatically hold in interchange between the buyer and representative of seller and/or bodily resources or goods and/or systems of the service provider, which are provided as results to customer needs (Gronroos, 2000). Services such as accepting deposits, deed lending, allowing business credits, fund transfer, clent portfolio, project financing, as well as other asset and counselling services are obtainable in banks. Therefore, service is a recognisable, impalpable action of business and the reason of existence primarily which is served to meet and exceed the expectations of existing and anticipated customers.

The definitions show that certain basic features of service and according to Angelova and Zekiri (2011), these are; Untouchability: This cannot be calculated for in quantitative term, its measurement, try out, confirmation and catalogue ahead of sale becomes practically impossible. Nearly all servicing organisations find it difficult to identify and assess how customers consider their services. Perishability: It is also practically impossible to preserve services for future whether for use or sales. When services are implemented, they are consumed immediately as such cannot be kept in a place. Also, when supply is below demand, it cannot be kept, by keeping.

Inseparability: There distinctions between physical goods and services in a number of grounds. In terms of production order and consumption for instance. Services are sold, manufactured and consumed immediately. Unlike tangible items which will first be manufactured, might be sold immediately or stored and or in the latter sold and consumed. Heterogeneity: An unescapable result of concurrent manufacture and consumption differ in service performance. That is, service quality may differ with reference to the firm that produced it, when and how it was produced. In service industry such as bank and insurance, those services differ with reference to the sub-sectors.

Attempts to harmonize 'service' and 'delivery' have been widely discussed in the literature. For instance, Gronroos (1984) described service delivery as 'a set of perceived discernments resulting from an assessment process where customers juxtapose service anticipated with service received'. Also, Herstein \& Gamliel (2006) described service delivery as the extent to which the level of service delivered to customers' equals what the customers anticipated. Customers' perspective on the description of service 
delivery suggest that it involves perceived quality of a service as against consumer expectations with the service as regard service received, that is puts the perceived service against the expected service (Gronroos, 1984).

Therefore, improving customer service delivery involves commitment to unravelling what customers' desire and wants on the one hand and evolving action plans that would address it. To achieve effectual service delivery in banks, employees should be emotionally intelligent and stable.

\subsection{Theoretical Review}

\subsubsection{Personality Theory}

This theory is based on individual traits which are attached to EI in individuals is made up of a range of emotional dispositions and competencies such as self-mindfulness, self-order, enthusiasm, empathy and adeptness in relationships. Accordingly, these traits predispose an individual to act in definite manner in different situations which McCrae and Oliver (1992) identified as the big five namely, frankness, conscientiousness, extraversion, agreeableness, and neuroticism. As such traits attributed to individuals is an attempt to know why or why not they behave in a particular way. This is no doubt influenced by their cognitive procedure and signal a sensation of order which can appear baseless, and awkward. In line with this, personality theory categorises people into types on the basis of personality tests and identified types of people along extraversion or introversion.

\subsubsection{Demand Control Theory}

Wall, Jackson, Mullarkey and Parker (1996) demands-control theoretical readjustment, or clarification, has not been carried through into quantity practice. Almost all investigators have continued to use scales based on Karasek's (1979) original measure of job decision latitude, which represents a much larger construct than that of job control. Decision latitude contains not only items concerned with job control, but also ones casing the extent to which the job involves the opportunity to learn new things, develop skills, exercise a high level of skill, show creativity, use one's capabilities and to experience variety (Karasek \& Theorell, 1990).

These theories rest on the premise that perceptions of customers and service provider about banking services are good determinants of service delivery (Zeithaml et al., 1988). With the literature review on service delivery, it is obvious that theory is required to underpin how efficiency level of service delivery can be determined viz a viz employees' emotional intelligence.

\subsection{Empirical Review}

Extant studies (Okon, et al., 2015; Kaura, 2011) have shown that EI is connected to service delivery. Opuni \& Adu-Gyamfi (2014) study of the Ghanaian telecommunication sector suggests that EI is positively related to management efficiency as regard service delivery and customer expectation levels. Specifically, the study of Kaura (2011) examined the enormity of EI in Indian banking sector and findings revealed a solid relationship between emotional intelligence and banks service quality. Likewise, the study of Okon et al., (2015) in Nigeria found out that EI confidently influences employees' service delivery among Nigerian banks.

Jain and Gupta (2014) investigated EI impact on service delivery of employees' in selected Indian banks that are privately owned with a sample of sixty-five (65) employees and EI among bank employees was assessed on five dimensions namely- self -mindfulness, emotions handling, self-motivation, emotions of others and relationship control. It was established that individuals with high emotional intelligence would perform better on the grounds of high levels of interpersonal skills. Pahuja and Sahi (2012) investigated the factors that affect EI among bank employees working in Punjab and examined how the factors determine their performance. The study was exploratory in nature. With one hundred and twenty (120) population of the study, consisting of bank employees in both private and public-sector. Employees' of the banks were found to be aware of this comparatively new concept 'EI'. It was revealed that male and female employees differ significantly as regards various EI traits.

Nyerere and Barasa (2015) examined the influence of EI on service delivery. Results indicate that social-talents, self-mindfulness, social-mindfulness, and self-controlling have influence on service delivery. To achieve this, trainings on the development of EI among employees in organisations, information, talents, and personality orientation should be promoted. Related study by Swarnalatha, and 
Sekar (2016) on the level of EI among bank revealed that there are four major factors affecting EI namely, Self- Mindfulness, Self- Control, Social-Talents and Empathy. It also revealed that EI plays a major role in bank employee's life, and all the employees have great EI. Also, there was no difference between EI and age of the employees.

Karimi (2014) examined the influence of self-mindfulness, self-controlling and relationshipsmanagement on employee performance. The study adopted exploratory method with seventy-six (76) employees of a Nairobi hotel but sampled thirty-eight (38) employees through simple random sampling. Data was collected through questionnaire and interviews means. Outcomes of the study showed that selfawareness, self-management and relationships-management proxies of EI influence employee performance.

Based on above review, it is obvious that the studies are still limited because none has captured the perception of customers' bank service delivery in developing countries and precisely Africa. It is thus expedient to investigate this and the study considered Nigeria and Liberia for this purpose. Furthermore, there is no substantial literature on employee EI involving Nigeria and Liberia.

\subsection{Methodology}

This study adopted survey research design. Survey design is the systematic study of phenomenon (Creswell, 2010) allowed the researcher to know what the situation is currently. To achieve this, deposit money banks in both Nigeria and Liberia were considered. In Nigeria, there are twenty-three (23) DMBs in Nigeria as at October 2019 (www.cbn.gov.ng). In Liberia, as of 2019, there were nine licensed deposit money banks operating in the country. Therefore, the study population covers all the banks in both countries and their respective bank employees and customers totalling of 32 banks.

With the population of the banks under study, a sample was considered in line with International Organisation for Standard Certification (IOSC) metrics of what makes 'Excellent Banks', namely, customer service, service quality, innovation and customer focus. In Nigeria, the leading bank is First Bank of Nigeria (Fitch Report, 2018) while in Liberia, Ecobank Liberia Limited is adjudged the leading bank. For the first category of respondents (Bank Staff): In Nigeria, four (4) main branches of First Bank Nigeria Limited exist in Lagos with sixty (60) full staff while in Liberia, three (3) main branches of Ecobank Liberia Limited exist in Monrovia with fifty (50) full staff. In the case of second Subject (Customers): This is made up of customers of the selected branches of the banks in both countries. Six hundred customers were targeted with First Bank of Nigeria (400) and Ecobank of Nigeria (200)

This study adopted purposive and convenience sampling techniques. In the instance of bank employees, purposive sampling was adopted while convenience sample was adopted for bank customers' selection. Data for this study was primarily sourced with the use of structured questionnaire. Two sets of questionnaires were designed for the study. The first set of questionnaires was designated for the bank staff. The research instrument is made up of two (2) sections that is, Sections A and B respectively. Data collected for the study was analysed using both descriptive and inferential statistics. Descriptive statistics include frequency distribution, mean and standard deviation were used while Inferential statistics such as Correlation matrix, Linear Regression and ANOVA were used too.

\subsection{Data Analysis Summary}

4.1 Assessment of Customers' Complaints Rate on Bank Services in the two Countries

Table 1: Customer Complaint rate on Bank Services

\begin{tabular}{|l|l|l|l|l|l|l|}
\hline \multirow{2}{*}{ Complaints } & \multicolumn{2}{l}{ N } & \multicolumn{2}{l|}{ Mean } & \multicolumn{2}{l|}{ Std. Deviation } \\
\cline { 2 - 7 } & Nigeria & Liberia & Nigeria & Liberia & Nigeria & Liberia \\
\hline Excellent Banking Services & 277 & 143 & 2.9170 & 2.5926 & 1.22340 & 1.03785 \\
Promptness from Employees & 277 & 143 & 3.0505 & 2.8025 & 1.67169 & .97599 \\
Error-Free Services from Employees & 277 & 143 & 2.8809 & 2.7202 & 1.22337 & 1.05033 \\
Knowledge on Specific Service & 277 & 143 & 3.0830 & 3.0905 & 1.18427 & 1.02451 \\
Needed of & & & & & & \\
Technological Knowledge of & 277 & 143 & 3.1119 & 3.0535 & 1.28752 & 1.08769 \\
Employees & & 143 & 3.2708 & 3.2634 & 1.28916 & 1.19424 \\
Improvement in Services & 277 & 143 &
\end{tabular}




\begin{tabular}{|c|c|c|c|c|c|c|}
\hline Creativity of Employees & 277 & 143 & 3.1697 & 2.8148 & 1.20239 & .84469 \\
\hline Problem Solving Skill of Employees & 277 & 143 & 3.1011 & 3.2716 & 1.26429 & 1.12094 \\
\hline $\begin{array}{l}\text { Change in level of interaction } \\
\text { between Service Provider and } \\
\text { Customer }\end{array}$ & 277 & 143 & 2.7329 & 2.8477 & 1.29132 & .87991 \\
\hline Excellent Speed of Service Provided & 277 & 143 & 3.2527 & 2.9630 & 1.40175 & 1.12571 \\
\hline
\end{tabular}

Source: Field Survey (2019).

Table 1 reveals customer complaint rate on bank services in Nigeria and Liberia. With 10 items, complaints related issues were sought in relation to banks services from the customers in both countries to generate their mean values, as complaints above mean values of 3.0 were not supported by the respondents while mean values below 3.0 are assumed to be complaints raised by the customers.

\subsection{Investigate Bank Employees' Emotional Intelligence Level in Both Countries}

Table 2: Employees Emotional Intelligence Level

\begin{tabular}{|c|c|c|c|c|c|c|}
\hline $\begin{array}{ll}\text { Emotional } & \text { Intelligence } \\
\text { Predictors } & \end{array}$ & \multicolumn{2}{|l|}{$\mathrm{N}$} & \multicolumn{2}{|l|}{ Mean } & \multicolumn{2}{|c|}{ Std. Deviation } \\
\hline & Nigeria & Liberia & Nigeria & Liberia & Nigeria & Liberia \\
\hline Social Skills & 46 & 48 & 15.5217 & 15.9792 & 4.05922 & 2.63761 \\
\hline Self-Management & 46 & 48 & 15.9348 & 16.2292 & 3.95195 & 2.12623 \\
\hline Social Awareness & 46 & 48 & 15.5652 & 15.2500 & 3.60649 & 2.62962 \\
\hline Self-Awareness & 46 & 48 & 16.2391 & 15.4375 & 3.53512 & 2.94565 \\
\hline Total & 46 & 48 & 15.8152 & 15.7240 & & \\
\hline
\end{tabular}

Source: Field Survey (2019).

Table 2 shows the level of employees' emotional intelligence in Nigeria and Liberia using the mean value of the four emotional intelligence predictors considered in this study. Social skill in Nigeria had a mean value of 15.5217 and Liberia had a mean value of 15.9792. Self-management in Nigeria had a mean value of 15.9348 and Liberia had a mean value of 16.2292. Social awareness in Nigeria had a mean value of 15.5652 and Liberia had a mean value of 15.2500, while Self-awareness in Nigeria had a mean value of 15.5652 and Liberia had a mean value of 15.2500. The grand mean from the four emotional intelligence predictor shows that there exists a higher level of emotional intelligence in Liberia than Nigeria although with just a slight difference. This is to say that there exists a closeness in the level of emotional intelligence in both countries.

Table 3: Regression Summary of employees' emotional intelligence predictors (Nigeria)

\begin{tabular}{|l|l|l|l|}
\hline $\mathrm{R}=92.3 \%$ \\
$\mathrm{R}^{2}=85.3$ \\
$\begin{array}{l}\text { Adjusted } \mathrm{R}^{2}=83.8 \% \\
\text { S.E.= } 2.95\end{array}$ & Beta $(\beta)$ & $\mathrm{T}$ & Sig \\
\hline & 1.060 & .469 & .642 \\
\hline Constant & .261 & 1.605 & .116 \\
\hline Social Skill & 1.093 & 4.860 & .000 \\
\hline Self-Management & .328 & 1.712 & .094 \\
\hline Social Awareness & .242 & 1.211 & .233 \\
\hline Self-Awareness & &
\end{tabular}

Source: Field Survey (2019).

Table 3 reveals that only one out of the four employees' emotional intelligence predictors significantly contribute to the quality of bank service delivery in Nigeria. Self-Management $(\beta=1.093, t$ $=4.860, \mathrm{p}<4.860)$ is the only significant contributor, while Social Skill $(\beta=0.261, t=1.605, \mathrm{p}>0.05)$, Social Awareness $(\beta=0.328, t=1.712, p>0.05)$ and Self Awareness $(\beta=0.242, t=1.211, p>0.05)$ were not significant contributors to quality bank service delivery. This implies that a unit change in selfmanagement will relatively increase the likelihood of improved quality of bank service delivery in Nigeria. 
Table 4: Regression Summary of employees' emotional intelligence predictors (Liberia)

$$
\mathrm{R}=73.3 \%
$$

\begin{tabular}{|l|l|l|l|}
\hline & $\operatorname{Beta}(\beta)$ & $\mathrm{T}$ & Sig \\
\hline Constant & 5.183 & 1.302 & .200 \\
\hline Social Skill & .432 & 2.402 & .021 \\
\hline Self-Management & .594 & 2.680 & .010 \\
\hline Social Awareness & .638 & 3.476 & .001 \\
\hline Self-Awareness & .029 & .175 & .862 \\
\hline
\end{tabular}

Source: Field Survey (2019).

Table 4 reveals that three out of the four employees' emotional intelligence predictors are significant contributors to the quality of bank service delivery in Liberia. Social Skill $(\beta=0.432, t=2.402, p$ $<0.05)$, Self-Management $(\beta=594, t=2.680, p<0.05)$ and Social Awareness $(\beta=0.638, t=3.476, p<0.05)$ were the predictors that significantly contribute to the quality of banks service delivery in Liberia, while Self Awareness $(\beta=0.029, \mathrm{t}=0.175, \mathrm{p}>0.05)$ is not a significant contributor. This implies that a unit change in the social skill, self-management and social awareness of employees will relatively increase the likelihood of improved quality of bank service delivery in Nigeria.

Table 5: Regression Summary (Nigeria)

$$
\begin{aligned}
& \mathrm{R}=.909^{\mathrm{a}} \\
& \mathrm{R} \text { Square }=.826
\end{aligned}
$$

Adjusted R Square $=.822$

\begin{tabular}{|l|l|l|l|l|l|l|}
\hline Model & & Sum of Square & df & Mean Square & F & Sig \\
\hline \multirow{7}{*}{} & Regression & 1995.066 & 1 & 1995.066 & 208.888 & .000 \\
\cline { 2 - 7 } & Residual & 420.239 & 44 & 9.551 & & \\
\cline { 2 - 7 } & Total & 2415.304 & 45 & & & \\
\hline
\end{tabular}

Source: Field Survey (2019).

Table 5 revealed that emotional intelligence predictors has a significant combined influence on bank service delivery in Nigeria. The table reveals $R=.909 a, R$ Square $=.826$, Adjusted $\mathrm{R}$ Square $=.822$. This suggests that the predictor accounts for $82.2 \%(.822)$ variance in the prediction of services being delivered by banks in Nigeria. The remaining variance is as a result of variables outside the scope of the study. The ANOVA Table further revealed that emotional intelligence has significant contribution on bank service delivery in Nigeria: $\mathrm{F}(1,44)=208.888, \mathrm{P}<0.01$.

Table 6: Regression summary (Liberia)

\section{$\mathrm{R}=.684^{\mathrm{a}}$ \\ $\mathrm{R}$ Square $=.468$}

Adjusted R Square $=.457$

\begin{tabular}{|l|l|l|l|l|l|l|}
\hline Model & & Sum of Square & Df & Mean Square & F & Sig \\
\hline \multirow{7}{*}{} & Regression & 341.107 & 1 & 341.107 & 40.506 & .000 \\
\cline { 2 - 7 } & Residual & 387.372 & 46 & 8.421 & & \\
\cline { 2 - 7 } & Total & 728.479 & 47 & & & \\
\hline
\end{tabular}

Source: Field Survey (2019).

Data in Table 6 revealed that emotional intelligence predictors have a significant combined influence on bank service delivery in Liberia. The table reveals $R=.684^{\mathrm{a}}, \mathrm{R}$ Square $=.468$, Adjusted $\mathrm{R}$ Square $=.457$. This suggests that the predictor accounts for $45.7 \%(.457)$ variance in the prediction of services being delivered by banks in Liberia. The remaining variance is as a result of variables outside the 
scope of the study. The ANOVA Table further revealed that emotional intelligence has significant contribution to bank service delivery in Liberia: $\mathrm{F}(1,46)=40.506, \mathrm{P}<0.01$.

\subsection{Discussion of Findings}

Based on the outcomes of the study, it is obvious that employees' emotional intelligence is fundamental to service delivery. Firstly, this study confirmed the existence of customers' complaints among bank customers' in both Nigeria and Liberia. This justified the need for the study and support the view of Alnsour (2013) which reported rising cases of customer complaints in the banking industry. Also, it was discovered that there is no significant difference between the employees' EI level of Nigeria bank employees and Liberia bank employees. This suggests the importance of employees' emotional intelligence in both countries. It was also affirmed that the level of emotional intelligence among bank employees in both Nigeria and Liberia is not really different. This finding corroborates result of Begum (2018), and Danquah (2015) which confirmed the importance of emotional intelligence among bank employees in this century.

Furthermore, self-management is the only significant contributor to quality of service delivery in Nigeria while social skill, social awareness and self-management were the predictors that significantly contribute to the quality of banks' service delivery in Liberia. This implies that the contributions of employee' emotional intelligence proxies differ because of the nature of service required by customers from the bank and may be because of bank context that is Nigeria or Liberia. This finding is not quite different from the results of Peter (2013) and Karimi (2014) which found self-awareness, and selfmanagement as leading contributors to performance in service delivery. It is also in consonance with the finding of Kappagoda (2013) which affirmed disparities in the level of emotional intelligence of bank employees' in Sri Lanka.

Lastly, result revealed that there is a significant combined influence of the predictors of employees' EI on bank service delivery to customers in both countries. All the four proxies of EI investigated in this study jointly influence service delivery in the two countries with different significance though. This finding corroborates the position of Swarnalatha, \& Sekar (2016) which revealed combined effect of EI predictors on bank service delivery and also advanced the findings of Nyerere \& Barasa (2015) that reported self-awareness, social-skills, self-management and social -awareness jointly influence service delivery.

\subsection{Conclusion}

Bank service delivery is strongly tied to employees' emotional intelligence. For banks to remain competitive and remain in business, it is expedient to appreciate the place of emotionally intelligent employees who will deliver services to customers. While many factors contribute to efficient bank service delivery, employees; emotional intelligence is significant. The outcomes of this research have shown this in both Nigeria and Liberia the contexts of the current study. However, predictors of employees' emotional intelligence such as social skills, self-management, self-awareness and social awareness differs in their contributions to bank service delivery. Self-management is of prime significance in Nigeria bank to service delivery while social skills, self-management and social awareness count more in Liberia bank.

\subsection{Recommendations}

Based on the findings of this study, the recommendations were divided into folds:

\section{To First Bank Management in Nigeria}

Social skills of employees' in the bank should be improved upon. The bank should constantly train employees on this and monitor the social relationship of their employees with customers because it is an embodiment of service delivery to the customers.

Social awareness creation among bank employees should be encouraged. This can be done through the promotion of necessary and relevant social issues to service delivery among employees at intervals.

Management of the bank are to ignite self-awareness among their employees. This can be initiated during orientation and refreshment programmes of the banks.

\section{To Ecobank Management in Liberia}

Self-awareness seems low and can be promoted to bring about excellent service delivery through employees of the bank. In this wise, employee self-discovery is important. 
Also, training programmes that can enrich proxies of emotional intelligence in employees should be frequently organised. Specifically, emotional intelligence training should be carried out at intervals in the bank.

\section{To First Bank Employees in Nigeria}

Social skills of employees' must be improved upon. Individual employees of the bank should consistently attend social skills acquisition programs to facilitate social interactions of employees with customers.

Employees require to be more sensitive to customers' needs as well as provide problem-based solutions to customers.

In order to reduce customer complaints, employees need to be curious about customers' challenge and show interest in solving the service problem confronting customers at all times.

\section{To Ecobank Employees in Liberia}

To improve service delivery efficiency, employees of the bank must seek knowledge personally on how to continuously aid their relationship with customers'

\section{References}

Adeniji, A. A. \& Akinbode, J. O. (2018). Knowledge of banking services among frontline personnel and quality of service delivery in the Nigerian commercial bank. Journal of Business and Retail Management Research (JBRMR), $12(3), 160-167$.

Alnsour, S. M. (2013). How to retain a bank customer: a qualitative study of Jordanian Banks Relational Strategies International Journal of Marketing Studies, 5(4), 123-131.

Angelova, B. \& Zekiri, J. (2011), Measuring customer satisfaction with service quality using American customer satisfaction model (ACSI Model). International Journal of Academic Research in Business and Social Sciences, 1(3), 232-258.

Armstrong, M. (2009). Armstrong's Handbook of Human Resource Management Practice (Eleventh edition). London: Kogan Page Limited

BarOn, R. (1997). The Bar on Emotional Quotient Inventory (EQ-i): A Test of Emotional Intelligence. Toronto, Canada: Multi-Health Systems.

Begum, M. M. (2018). Emotional intelligence in banks-an empirical study with reference to selected banks of Vijayawada City. IOSR Journal of Business and Management (IOSR-JBM), 20(10), 74-87.

Chapman, M. (2011) Emotional Intelligence Pocketbook. Pocketbooks.

Consoli, D. (2010). A new concept of marketing: The emotional marketing. Broad Research in Accounting, Negotiation, and Distribution, 1(1), 1-8.

Creswell, J. W. (2010). Research design: Qualitative, quantitative, and mixed methods approaches. London: Sage publications.

Danquah, E. (2015). The effect of emotional intelligence on the financial performance of commercial banks in Ghana: The mediation role of relationship marketing, service quality, customer satisfaction. British Journal of Marketing Studies, 3(2), 8-25.

Farayibi, A. (2016). Service delivery and customer satisfaction in Nigerian banks. Munich Personal RePEc Archive, Paper No. 73612, 1-15.

Fitch ratings (2017). Report on Bank Rating. London and New York (accessed from www.fitchratings.com).

Georgiana, D. (2014, November 02). Emotionskills.com. Retrieved October 12, 2019, from http://www.emotionskills.com/fourdimensions-of-emotional-intelligence/

Goleman, D. (1995). Emotional Intelligence. New York: Bantam

Goleman, D. (1998). Working with Emotional Intelligence. New York: Bantam Books.

Graham, H. T., \& Roger, B. (1998). Human resource management. 6th Ed. London: Prentice hall.

Gronroos, C (2000), Service management and marketing: a customer relationship management approach. 2nd edition. New York, Chichester: Wiley and Sons, Ltd.

Gronroos, C. (1984). A service quality model and its marketing implications. European Journal of Marketing, 18(4), 3644.

Grönroos, C., \& Ravald, A. (2011). Service as business logic: implications for value creation and marketing. Journal of Service Management, 22(1), 5-22.

Herstein, R., \& Gamliel, E. (2006). The role of private branding in improving service quality. Managing Service Quality, 16(3), 306-319.

Jain, S., Jain, V., and Das, S. (2018). Relationship analysis between emotional intelligence and service quality with special evidences from Indian banking sector. Revista ESPACIOS, 39(33), 3-13. 
Jain, V. \& Gupta, S. (2014). The impact of emotional intelligence on service quality in Indian Private Banks: with special reference to Moradabad city. International Journal of Advanced Research in Management and Social Sciences, 3(12), 264-274.

Kalpana, A. \& Noopur, S. (2013). Effect of emotional intelligence on customer retention amongst bank employees. International Journal of Business Management \& Research (IJBMR), 3(2), 60-66.

Kappagoda, S. (2013). Emotional intelligence of the managers in the banking Sector in Srilanka. International Journal of Research in Commerce, IT and Management, 3(6), 1-6.

Karasek R. (1979). Job demands, job decision latitude, and mental strain. Implications for redesign. Administrative Science Quarterly, 24, 285-307.

Karasek, R., \& Theorell, T. (1990). Healthy Work: Stress, Productivity and the Reconstruction of Working Life. New York: Basic Books.

Karimi, L. (2014). Emotional rescue: The role of emotional intelligence and emotional labour on well-being and job-stress among community nurses. Journal of Advanced Nursing, 70(1), 176-186.

Karthikeyan, V. \& Lalwani, S. (2017). Emotional intelligence in banking sector - an integrative literature review. Journal of Business and Management (IOSR-JBM), 19(10), 9-14.

Kaura, P (2011). Enormity of emotional intelligence in Indian banking sector. Asia Pacific Journal of Research in Business Management, 2(1), 165-177.

Killgore, W.D.S., Smith, R., Olson, E. A., Weber, M., Rauch, S.L., and Nickerson, L.D. (2017). Emotional intelligence is associated with connectivity within and between resting state networks. Social Cognitive and Affective Neuroscience, 12(10), 1624-1636.

Mayer, J. D., \& Salovey, P. (1990). What is emotional intelligence: In P. Salovey, \& D. Sluyter (Eds.). Emotional development and emotional intelligence: Implications for educators (pp. 3-31). New York: Basic Books.

McCrae R., \& Oliver P. (1992) An introduction to the Five-factor Model and the applications,

University of California, Berkeley.

Naeem, H., Saif, M. I., \& Khalil, W. (2008). Emotional intelligence and its impact on service quality: Empirical evidence from the Pakistani banking sector. International Business \& Economics Research Journal, 7(12), 55-62.

Nyerere, K. J. \& Barasa, P. W. (2015). The influence of emotional intelligence on service delivery. International Journal of Economics, Finance and Management, 4(1), 8-13.

Odusina, A. O. (2014). Automated teller machine usage and customers' satisfaction in Nigeria. Global Journal of Management and Business Research: C Finance 14(4), 68-74.

Okon, E. E., Anietie, P. A., \& Abosede, A. (2015). Emotional intelligence and employee performance: Evidence from the Nigerian banking industry. International Journal of Management and Business Studies, 5(2), 76-80.

Opuni, F. F., \& Adu-Gyamfi, K. (2014). An analysis of the impact of emotional intelligence on service quality and customer satisfaction in the telecommunication. International Journal of Sales \& Marketing Management Research and Development (IJSMMRD), 5(1), 38-52.

Pahuja, A. and Sahi, A. (2012) Emotional intelligence (EI) among bank employees: An empirical Study. Afro Asian Journal of Social Sciences, 3(3), 2-18.

Parasuraman, A., Zeithaml, V.A. and Berry, L.L. (1985), A conceptual model of service quality and its implication. Journal of Marketing, 49(4), 41-50.

Peter, O. A. (2013). An assessment of the effect of emotional intelligence on leadership performance in Local Government Administration. Journal of Emerging Trends in Economics and Management Sciences (JETEMS), 5(1), 44-50.

Sanusi, L. S. (2012). Banking reform and its impact on the Nigerian economy. Paper presented at the University of Warwick's Economic Summit, Warwick, 17 February 2012, 1-7.

Shahram, G., Mohmmad, T., \& Mohammad, R.K.T (2013). The impact of service quality on customer satisfaction. Journal of Research and Development, 1, (4), 1-7.

Swarnalatha, V., \& Sekar, S. (2016). A study on emotional intelligence among bank employees. International Journal of Engineering Technology, Management and Applied Sciences, 4(4), 201-205.

Thavaraj, H. (2012). A study on identifying the level of emotional intelligence among bank managers in Madurai district, south India. Researchers World: Journal of Arts, Science E Commerce, 4(2), 58-67.

Wechsler, D. (1958). The measurement and appraisal of adult intelligence (4th ed.). Baltimore, MD: Williams \& Wilkins.

Zeithaml, V. A., Berry, L. L. \& Parasuraman, A. (1988). Communication and control processes in the delivery of service quality. Journal of Marketing, 52(April), 35-48. 